\title{
PENINGKATAN KEMAMPUAN PEMECAHAN MASALAH MATEMATIKA MAHASISWA MELALUI PEMBELAJARAN DENGAN PENDEKATAN PETA KONSEP
}

(Studi Eksperimen Pada Mata kuliah Matematika Dasar di prodi Matematikan di Fakultas Tarbiyah dan keguruan UIN SGD Bandung)

Asep Jihad

Dosen FTK UIN Bandung

asjiehad2006@yahoo.co.id

\begin{abstract}
Abstrac
Generally in lecturing execution in Prodi Mathematics in Tarbiyah and Teachership Faculty UIN Bandung, dosen use the method of drill and practice, student hear and note the discourse dosen later finish the practice problem. Condition that way result the passive student, result of lecturing and ability of trouble-shooting of student mathematics is not optimal, in consequence require to develop the lecturing which can push the active student one of them is with the approach of concept map.

This Experiment research aim to to analyse the make-up of ability of trouble-shooting of student mathematics Prodi Mathematics in Tarbiyah and Teachership Faculty UIN Bandung passing approach of concept map. Data collected by tes Problem solving matematka and attitude scale.
\end{abstract}

Result of research of approach of concept map can improve the ability of problem solving student in subjek mater Elementary Mathematics.

Key word: concept, map, Mathematics

\section{Pendahuluan}

Sebagai ilmu yang mengedepankan logika berpikir, dalam memahami konsep matematika diperlukan kemampuan generalisasi serta abstraksi yang cukup tinggi. Sedangkan saat ini penguasaan peserta didik terhadap materi konsepkonsep matematika masih lemah bahkan dipahami dengan keliru.

Umumnya dalam pelaksanaan perkuliahan di Prodi Matematika Fakultas Tarbiyah dan Keguruan UIN Bandung, dosen menggunakan metode drill and practice, mahasiswa mendengar dan mencatat apa yang diceramahkan oleh dosen kemudian dilanjutkan dengan menyelesaikan soal-soal latihan. Materi yang diberikan pada mahasiswa sudah dalam bentuk final, mahasiswa hanya menerima begitu saja tanpa mengetahui tentang bagaimana, mengapa dan untuk apa materi tersebut diberikan. Akibatnya mahasiswa hanya belajar secara hafalan tanpa memahami makna dari materi yang dipelajarinya. Indikasi ini juga tampak dari banyaknya mahasiswa saat menghadapi soal-soal yang belum diberikan contohnya, mereka tidak dapat menyelesaikan meskipun hanya dapat menyebutkan apa yang diketahui dan yang ditanyakan dari soal tersebut.

Kondisi ini wajar jika sampai saat ini, hasil belajar mahasiswa di Prodi Matematika Takultas Tarbiyah dan Keguruan UIN Bandung yang mendapat nilai $\mathrm{C}$ dan $\mathrm{D}$ masih lebih besar dibandingkan dengan nilai $\mathrm{A}$ dan $\mathrm{B}$ pada mata kuliah Bidang Matematika. Identifikasi terhadap penyebab rendahnya hasil perkuliahan Bidang Matematika bersumber dari permasalahan berikut, yakni: (1) pembelajaran mata kuliah Bidangn Matematika belum pernah berdasarkan pada pengetahuan awal dan keterampilan awal mahasiswa, (2) perkuliahan mata kuliah Matematika belum banyak menyentuh aspek psikomotor mahasiswa secara optimal, (3) hampir $85 \%$ mahasiswa menyatakan dirinya kurang mendapat kesempatan untuk melakukan eksplorasi dalam 
membangun penguatan Matematika dalam kehidupan praktis.

Dalam upaya meningkatkan kualitas perkuliahan bisa dilakukan melalui perbaikan sistem perkuliahan. Salah satu bentuk perbaikan yakni melalui perkuliahan bermakna, dimana dalam setiap perkuliahan yang dilakukan dosen adalah mengaitkan bahan kuliah dengan konsep-konsep relevan yang telah dimiliki mahasiswa dan hal ini akan menjadi semakin bermakna bila mahasiswa ikut aktif dalam kegiatan pembelajaran itu serta penyampaian materi tersebut melibatkan proses berpikir mahasiswa.

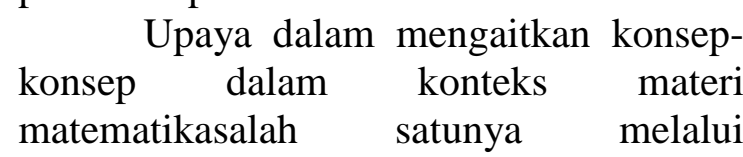
pendekatanpeta konsep. Pembelajaran matematika disertai penyusunan peta konsep memungkinkan mahasiswa terlibat aktif dalam proses berpikir mengaitkan konsep-konsep relevan yang dimiliki sebelumnya dengan informasi baru yang sedang disampaikan oleh dosen pada perkuliahan. Pembelajaran bermakna dengan mengembangkan peta konsep bisa dilakukan untuk seluruh mata kuliah bidang matematika, salah satunya untuk mata kuliah Matematika Dasar.

Berawal dari pemikiran di atas, maka peneliti tertarik untuk melakukan penelitian perkuliahan matematika dasar dengan menggunakan peta konsep untuk melihat gambaran kemampuan pemecahan masalah mahasiswa.

Selain itu, peneliti adalah dosen pengasuh mata kuliah Matematika Dasar pada mahasiswa Program Studi Pendidikan Matematika Fakultas Tarbiyah UIN SGD Bandung. Dengan demikian, penelitian bekaitan dengan penggunaan Peta Konsep meningkatkan kemampuan pemecaham masalah matematika mahasiswa dalam perkuliahan Matematika Dasar di Program Studi Pendidikan Matematika Fakultas Tarbiyah UIN SGD Bandung.

Ketertarikan dalam penelitian ini dalam rangka melakukan kontruksi perkuliahan agar melahirkan hasil perkuliahan dengan menggunakan berbagai pendekatan perkuliahan yang bisa mengembangkan komunikasi fikir antara mahasiswa dan dosesn sehingga melahirkan perkuliahan yang berkualitas dan dapat membatu mahasiswa agar hasil perkuliahannya optimal

Penelitian dirumuskan dalam pertanyaan-pertanyaan berikut : 1) Bagaimana pencapaian hasil perkuliahan matematika dasar mahasiwa prodi Matematika sebelum pembelajaran melalui peta konsep? 2)Bagaimana pencapaian hasil perkuliahan matematika dasar mahasiwa prodi Matematika melalui penyusuanan peta konsep? 3)Apakah terdapat peningkatan hasil perkuliahan setelah perkuliahan menggunakan menyusun peta konsep pada mata Kuliah Matematika Dasar? 4)Bagaimana sikap mahasiswa terhadap perkuliahan menggunakan menyusun peta konsep pada mata kuliah Matematika Dasar?

Tujuan penelitian ini dilakukan untuk menelaah dan menganalisis: 1) Pencapaian hasil perkuliahan Matematika Dasar mahasiwa prodi Matematika sebelum pembelajaran melalui peta konsep; 2)Pencapaian hasil perkuliahan Matematika Dasar mahasiwa prodi Matematika melalui penyusuanan peta konsep; 3)Menelaah peningkatan hasil perkuliahan setelah perkuliahan menggunakan menyusun peta konsep pada Mata Kuliah Matematika Dasar. Dan 4) sikap mahasiswa terhadap perkuliahan menggunakan menyusun peta konsep pada Mata Kuliah Matematika Dasar.

\section{Landasan Teoritis}

Aktivitas mahasiswa dalam perkuliahann dapat terbentuk dengan baik melalui model pembelajaran yang tepat yang didesain oleh dosen. Model pembelajaran yang tepat dapat meningkatkan tingkat pembelajaran dari kemampuan berpikir tingkat rendah (low order thinking skills) seperti mengamati, mengingat dan menggali kembali ingatan, serta pengetahuan akan gagasan umum berkenaan dengan pertanyaan apa, dimana 
dan kapan, ke tingkat kemampuan berpikir yang lebih tinggi (high order thinking skills) seperti memecahkan masalah, analisis, sintesa, evaluasi, berkenaan dengan pertanyaan bagaimana dan mengapa. Langkah-langkah dalam model pembelajaran yang mendorong mahasiswa berpikir tingkat tinggi yakni mahasiswa memilih subtopik khusus sendiri; mahasiswa diorganisasi menjadi kelompok-kelompok yang berorientasi pada tugas (task oriented groups) yang beranggotakan 5 hingga 6 orang, mahasiswa dan dosen membuat perencanaan, mahasiswa menerapkan rencana, mahasiswa menganalisis dan mengevaluasi informasi, kemudian beberapa atau semua kelompok menyajikan hasil penyelidikannya.

Howard (dalam Rahayu Condro Murti, 1998) berpendapat bahwa "Mengajar adalah suatu aktivitas untuk mencoba menolong, membimbing seseorang untuk mendapatkan, mengubah, atau mengembangkan kecakapan, sikap, cita-cita, penghargaan, dan pengetahuan." Dengan pengertian ini pendidik harus berusaha membawa perubahan tingkah laku yang baik. Untuk itu dosen harus merumuskan tujuan yang jelas dan memikirkan bagaimana bentuk cara penyajian dalam proses belajar mengajar sehingga terjadi interaksi edukatif.

Pendekatan belajar mengajar pada hakekatnya adalah suatu upaya dalam mengembangkan keaktifan belajar yang dilakukan oleh mahasiswa dan pendidik. Jadi pendekatan yang digunakan berkaitan dengan teknik penyajian materi pengajaran yang dilakukan dosen kepada mahasiswa sehingga terjadi interaksi antara dosen dan mahasiswa. Pendekatan yang dapat dilakukan dosen dalam memberikan kuliah di antaranya dengan pendekatan spiral, pendekatan induktif, pendekatan deduktif, pendekatan formal, pendekatan informal, pendekatan peta konsep. Penggunaan pendekatan-pendekatan tersebut pada dasarnya merupakan aplikasi dari beberapa teori belajar, seperti pada pendekatan peta konsep. Pada prinsipnya merupakan pendekatan peta konsep suatu pendekatan mengajar yang mengacu pada teori belajar Ausubel (Dahar, 1989), yaitu belajar bermakna. Dengan demikian pendekatan mengajar merupakan suatu prosedur yang digunakan dosen dalam menjelaskan suatu bahan pelajaran untuk mencapai tujuan belajar mengajar.

David Ausubel (1963) Pembelajaran bermakna merupakan suatu proses mengkaitkan informasi baru pada konsepkonsep relevan yang terdapat dalam struktur kognitif seorang. Struktur kognitif ialah fakta-fakta, konsep-konsep, dan generalisasi-generalisasi yang telah dipelajari dan dingat peserta didik. Semetara itu, Dahar (1996) mengemukakan dua prasyarat terjadinya belajar bermakna, yaitu: (1) materi yang akan dipelajari harus bermakna secara potensial, dan (2) anak yang akan belajar harus bertujuan belajar bermakna. Di samping itu, kebermaknaan potensial materi pelajaran bergantung kepada dua faktor, yaitu (1) materi itu harus memiliki kebermaknaan logis, dan (2) gagasangagasan yang relevan harus terdapat dalam struktur kognitif peserta didik.

$$
\text { Muchlas Samani }
$$
mengemukakan bahwa apapun metode pembelajarannya, maka harus bermakna (meaningfull learning). Pembelajaran bermakna merupakan suatu proses mengaitkan informasi baru pada konsepkonsep relevan yang terdapat dalam struktur kognitif seseorang. Struktur kognitif ialah fakta-fakta, konsep-konsep dan generalisasi-generalisasi yang telah dipelajari dan diingat siswa.

$$
\text { David Ausubel }
$$
mengklasifikasikan belajar dalam dua dimensi. Pertama, menyangkut cara penyajian materi diterima oleh peserta didik. Melalui dimensi ini, peserta didik memperoleh materi/informasi melalui penerimaan dan penemuan. Maksudnya peserta didik dapat mengasimilasi informasi/materi pelajaran dengan penerimaan dan penemuan. Dimensi 
kedua, menyangkut cara bagaimana peserta didik dapat mengaitkan informasi atau materi pelajaran dengan struktur kognitif yang telah ada. Jika peserta didik hanya mencoba-coba menghafalkan informasi atau materi pelajaran baru tanpa menghubungkannya dengan konsepkonsep atau hal lainnya yang ada dalam struktur kognitifnya, maka terjadilah yang disebut dengan belajar hafalan. Sebaliknya, jika peserta didik menghubungkan informasi atau materi pelajaran baru dengan konsep-konsep atau hal lainnya yang telah ada dalam struktur kognitifnya, maka terjadilah yang disebut dengan belajar bermakna.

Peta konsep (Concept Maps) dikembangkan Tony Buzan pada tahun 1970-an merupakan teknik memetakan konsep atau teknik mencatat informasi yang disesuaikan dengan cara otak memproses informasi yang memfungsikan otak kanan dan otak kiri secara sinergis (bersamaan dan saling melengkapi) sehingga informasi lebih banyak dan lebih mudah diingat ( DePorter, dkk. 2000 dan DePorter dan Hernacki, 2002). Svantesson (2004) mengatakan teknik ini dapat digunakan untuk membuat ringkasan buku dan ringkasan kuliah serta ketika membutuhkan struktur.

Peta konsep berbentuk suatu gambar keseluruhan dari suatu topik. Gagasan utama diletakkan di tengahtengah halaman dan sering dilengkapi dengan lingkaran, persegi, atau bentuk lain. Dari gagasan utama, ditambahkan cabang-cabang untuk setiap point atau gagasan utama. Jumlahnya bervariasi tergantung dari jumlah gagasan atau segmen. Tiap-tiap cabang dikembangkan untuk detail dengan menuliskan kata kunci atau frase dan dapat pula berupa singkatan. Sedangkan simbol-simbol dan ilustrasiilustrasi dapat ditambahkan untuk menambatkan ingatan yang lebih baik. Ditambahkan pula bahwa peta konsep terbaik adalah peta konsep yang warnawarni dan menggunakan banyak gambar dan simbol; biasanya tampak seperti karya seni ( DePorter, dkk. 2000, DePorter dan Hernacki, 2002, Svantersson, 2004).

$$
\text { Ratna Wilis Dahar }
$$
mengemukakan bahwa penggunaan konsep dalam pembelajaran dapat diketahui dengan pertolongan peta konsep. "Peta konsep digunakan untuk menyatakan hubungan yang bermakna antara konsepkonsep yang berbentuk preposisi-preposisi. Preposisi-preposisi merupakan dua atau lebih konsep-konsep yang dihubungkan oleh kata-kata dalam suatu unit semantik."Peta konsep adalah suatu gambar (visual), tersusun atas konsepkonsep yang saling berkaitan sebagai hasil dari pemetaan konsep. Pemetaan konsep diartiakan sebagai suatu proses yang melibatkan identifikasi konsep-konsep tersebut dalam suatu hierarki, mulai dari yang paling inklusif kemudian yang kurang inklusif setelah itu baru konsep-konsep yang lebih spesifik. Pemetaan konsep merupakan salah satu cara untuk mengeksternalisasikan konsep-konsep yang telah diperoleh beserta hubungannya. Dari peta konsep yang dibuat dapat dilihat keutuhan (unity) dari bangunan pengatahuan yang dimiliki. Dari peta konsep juga dapat diketahui keluasaaan dan kedalaman pemahaman akan konsepkonsep yang dipelajari.

Dahar (1988: 153) mengemukakan ciriciri peta konsep sebagai berikut:

1) Peta konsep (pemetaan konsep) adalah suatu cara untuk memperlihatkan konsep-konsep dan proposisi-proposisi suatu bidang studi, apakah itu bidang studi fisika, kimia, biologi, matematika dan lain-lain. Dengan membuat sendiri peta konsep siswa "melihat" bidang studi itu lebih jelas, dan mempelajari bidang studi itu lebih bermakna;

2) Suatu peta konsep merupakan suatu gambar dua dimensi dari suatu bidang studi atau suatu bagian dari bidang studi. Ciri inilah yang memperlihatkan 
hubungan-hubungan

proposisional antara konsepkonsep. Hal inilah yang membedakan belajar bermakna dari belajar dengan cara mencatat pelajaran tanpa memperlihatkan hubungan antara konsep-konsep;

3) Ciri yang ketiga adalah mengenai cara menyatakan hubungan antara konsepkonsep. Tidak semua konsep memiliki bobot yang sama. Ini berarti bahwa ada beberapa konsep yang lebih inklusif dari pada konsep-konsep lain;

4) Ciri keempat adalah hirarki. Bila dua atau lebih konsep digambarkan di bawah suatu konsep yang lebih inklusif, terbentuklah suatu hirarki pada peta konsep tersebut.

Menurut Nur (2000) dalam Erman (2003: 24) peta konsep ada empat macam yaitu: pohon jaringan (network tree), rantai kejadian (events chain), peta konsep siklus (cycle concept map), dan peta konsep labalaba (spider concept map).

Pemecahan masalah merupakan satu proses berfikir ilmiah. "Problem solving has been defined as higher-order cognitive process that requires the modulation and control of more routine or fundamental skills (Goldstein \& Levin, 1987). Pemecahan masalah di definisikan sebagai proses kognitif tingkat lebih tinggi yang memerlukan modulasi dan kontrol kecakapan-kecakapan yang lebih rutin dan fundamental. Termasuk pemecahan ini adalah penemuan masalah (problem finding) dan perumusan masalah (problem shaping).

Dalam kontek matematika pemecahan masalah menurut Gagne (Ruseffendi, 2006:335) pemecahan masalah adalah tipe belajar yang tingkatannya paling tinggi dan kompleks dibandingkan dengan tipe belajar lainnya.

Menurut Polya (2005) Pemecahan masalah merupakan suatu aktivitas intelektual yang sangat tinggi sebab dalam pemecahan masalah siswa harus dapat menyelesaikan dan menggunakan aturanaturan yang telah dipelajari untuk membuat rumusan masalah. Aktivitas mental yang dapat dijangkau dalam pemecahan masalah antara lain adalah mengingat, mengenal, menjelaskan, membedakan, menerapkan, menganalisis dan mengevaluasi.

Problem solving muncul sebagai salah satu perhatian disemua pendekatan sekolah. The National of Supervisor of Matematics (NCSM) menyatakan "belajar menyelesaikan masalah adalah alasan utama untuk mempelajari matematika. Premis tersebut tidak berubah banyak dari tahun ketahun, dan kemudian menjadi suatu perihal kuat. Bahkan dinyatakan secara tegas (NCTM: 2000) "Problem solving bukan sekedar tujuan dari belajar matematika tetapi juga merupakan alat untuk melakukannya kemudian mengutarakan bahwa strategi-strategi problem solving hendaknya dipelajari dari waktu ke waktu, diterapkan dalam konteks konteks tertentu, serta menjadi lebih khusus, terperinci, dan fleksibel seiring dipakai dalam situasi-situasi masalah yang kian komplek serta sepenuhnya sependapat". Pada kenyataanya kita sependapat bahwa problem solving bukan sekedar suatu keterampilan untuk diajarkan dan digunakan dalam matematika tetapi juga keterampilan yang akan dibawa pada masalah-masalah keseharian atau situasi pembuatan keputusan, dengan demikian membantu seseorang secara baik dalam pembuatan keputusan hidupnya.

Menurut Polya (Suryadi dkk, 2008: 70) dalam bukunya yang berjudul How to Solve It mengemukakan empat tahap proses pemecahan masalah dengan langkah-langkah sebagai berikut:
a) Memahami masalah,
b) Merencanakan penyelesaian masalah
c) Melaksanakan rencana penyelesaian masalah atau perhitungan
d) Pemeriksaan kembali 


\section{Hipotesis Penelitian}

Hipotesis yang diajukan pada penelitian ini adalah terjadi peningkatan kemampuan pemecahan masalah matematik mahasiswa yang mengikuti pembelajaran matematik dengan pendekatan tematik. Berdasarkan hipotesis penelitian yang diajukan tersebut, hipotesis nol $\left(\mathrm{H}_{0}\right)$ yang diuji adalah sebagai berikut:

$\mathrm{H}_{0}: \square_{\mathrm{e}}=\square_{\mathrm{k}}$,

Tidak terjadi peningkatan kemampuan pemecahan masalah matematik mahasiswa yang mengikuti pembelajaran matematik dengan pendekatan peta konsep

\section{Metode dan Prosedur Penelitian}

Dalam penelitian ini penulis menggunakan Desain yang digunakan dalam penelitian ini adalah one time series design (eksperimen seri waktu). Eksperimen seri waktu adalah suatu perluasan dari rancangan pretest dan posttest. Pretestnya tidak hanya dilakukan sekali tetapi beberapa kali, begitu pula posttestnya. Maksudnya adalah untuk melihat apakah skor-skor pada pretest tetap atau tidak, begitu pula skor-skor pada posttest. Secara desin penelitian ini disajikan disajikan pada gambar 1

\begin{tabular}{|c|c|c|}
\hline Pretest & Treatment & Posttest \\
\hline $\mathrm{T}_{1}, \mathrm{~T}_{2}$, & $\mathrm{X}$ & $\mathrm{T}_{1}{ }^{1}, \mathrm{~T}_{2}{ }^{1}$ \\
\hline
\end{tabular}

Gambar 1 Desain Penelitian

Keterangan :

$\mathrm{T}_{1}=\mathrm{T}_{1}^{1}, \mathrm{~T}_{2}=\mathrm{T}_{2}^{1}$

$\mathrm{T}_{1}, \mathrm{~T}_{2,}=$ Pretest (kemampuan pemecaham masalah matematika mahasiswa)

$\mathrm{T}_{1}{ }^{1}, \mathrm{~T}_{2}{ }^{1}, \quad=$ Postest

$\mathrm{X} \quad=$ Treatment khusus yaitu penerapan model pembelajaran peta konsep untuk kelompok eksperimen.

Sumber data dalam penelitian ini diperoleh dari: Dosen dan mahasiswa semester I Program Studi Pendidkan Matematika UIN Sunan Gunung Djari Bandung yang mengambil mata kuliah matematika Dasar tahun perkuliahan 20132014.

Variabel adalah kondisi-kondisi atau karakteristik yang oleh pengeksperimen dimanipulai, dikontrol dan diobservasi (Faisal, $1982: 82$ ).

Berdasarkan pendapat tersebut, maka variable-variabel tersebut yaitu :

a. Variabel Bebas : Pembelajaran matematika dengan model pembelajaran peta konsep.

b. Variabel Terikat : Kemampuan pemecahan masalah matematika mahasiswa.

Populasi dalam penelitian ini adalah mahasiswa semester I Program Studi Pendidkan Matematika UIN Sunan

Gunung Djari Bandung yang mengambil mata kuliah matematika Dasar tahun perkuliahan 2013-2014 yang berjumlah 43 mahasiswa. Dari jumlah populasi sebesar 266 anak tersebut, selanjutnya ditetapkan besarnya sampel dengan teknik total sampling, yaitu cara pengumpulan sampel dari anggota seluruh anggota populasi

Teknik pengumpulan datanya dilakukan melalui kuesioner, observasi dan test. Kuesioner digunakan untuk mengungkap sikap mahasiswa terhadap perkulaihan matematika dasar dengan menggunakan peta konsep. Sedangkan observasi digunakan untuk mengungkap pelaksanaan perkuliahan dengan menggunakan pendekatan peta konsep pada mata kuliah matematika Dasar. Dengan istrumen 1) tes pemecahan masalah, angket dan observasi

Hasil Penelitian dan Pembahasan 
Untuk melihat kemampuan anak dalam pemecahan masalah dengan pendekatan peta konsep adalah sebagai berikut:

Tabel 1

Rekapitulasi Skor Pretes Postes Pertama

Kemampuan Pemecahan Masalah Matematika

\begin{tabular}{|c|l|l|l|l|l|}
\hline Aspek & $\begin{array}{l}\text { Skor } \\
\text { Maksimum }\end{array}$ & $\boldsymbol{x}_{\text {min }}$ & $\boldsymbol{x}_{\text {maks }}$ & $\bar{x}$ & $\mathbf{S}$ \\
\hline Pretes-1 & 100 & 12 & 88 & 70.48 & 7.16 \\
\hline Postes 1 & 100 & 58 & 76 & 46.00 & 11.21 \\
\hline
\end{tabular}

Tabel 2

Rekapitulasi Data Postes 2

\begin{tabular}{|c|c|c|c|c|c|}
\hline Aspek & $\begin{array}{l}\text { Skor } \\
\text { Ideal }\end{array}$ & $x_{\min }$ & $x_{\text {maks }}$ & $\bar{x}$ & $\mathrm{~S}$ \\
\hline Pretes-2 & 100 & 72 & 24 & 70.12 & 5,8 \\
\hline Postes 2 & 100 & 88 & 44 & 52.8 & 9,73 \\
\hline \multicolumn{6}{|c|}{$\begin{array}{l}\text { Rata-rata Kemampuan Pemecahan Masatah } \\
\text { Pretes-2 dan Postes-2 }\end{array}$} \\
\hline 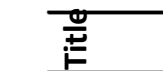 & & & & \multicolumn{2}{|c|}{ pretes-2 } \\
\hline$\frac{y}{\frac{y}{x}}$ & & & & \multicolumn{2}{|c|}{$\overline{\text { postes-2 }}$} \\
\hline & & & & & \\
\hline & & & & & \\
\hline
\end{tabular}

Gambar 2; Diagram Batang Data Rata-rata Pretes dan Postes-2

Untuk

melihat peningkatan kemampuan

peme

cahan masalah matematik, mahasiswa setelah mengikuti pembelajan pendekatan peta konsep diuji dengan melihat gain untuk tes pertama dan keduah dengan menghitung gain kedua kelompok

dengan menggunakan rumus gain ternormalisasi. Hasil perhitungan gain ternormalisasi selengkapnya disajikan pada Tabel 3.

Tabel 3

Gain Ternormalisasi Tes Pertama dan Kedua

\begin{tabular}{|c|c|c|}
\hline Aspek & $\begin{array}{c}\text { Rata2 Gain } \\
\text { Ternormalisasi }\end{array}$ & Kategori \\
\hline Postes 1 & 0,55 & Sedang \\
\hline Postes 2 & 0,41 & Sedang \\
\hline
\end{tabular}


Jurnal Analisa Prodi Pendidikan Matematika UIN Sunan Gunung Djati Bandung

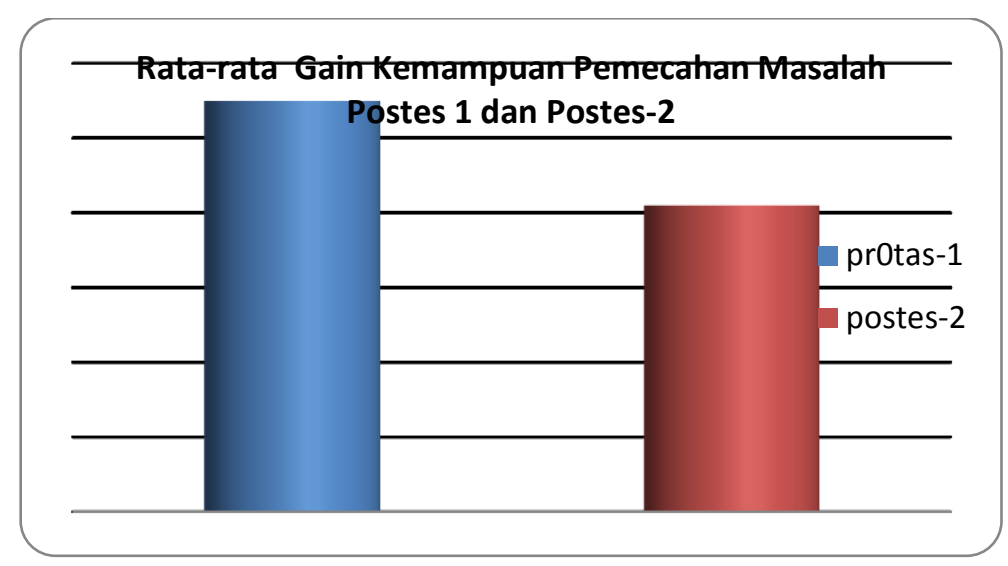




\section{Pembahasan}

Setelah melakukan penelitian diperoleh informasi-informasi sebagai berikut: 1) Pencapaian hasil perkuliahan Matematika Dasar mahasiwa prodi Matematika sebelum pembelajaran melalui peta konsep tergolong kategori rendah, baik untuk tes awal pertama maupun tes awal kedua sekalipun ada peningkatan dengan pencapaian rata-rata sebesar 46 dan skor tertinggi 76 dan terendah 12 untuk tes awal pertama dan rata-rata sebesar 52, dengan nilai terendah 24 dan tertinggi 72, adapun sekala yang digunakan adalah 100.2)Pencapaian hasil perkuliahan Matematika Dasar mahasiwa prodi Matematika melalui penyusuanan peta konsep, diperoleh dengan pembelajaran melalui peta konsep tergolong kategori baik, untuk tes akhir pertama maupun tes akhir kedua dan menunjukan peningkatan dengan pencapaian rata-rata sebesar 70,48 dan skor tertinggi 88 dan terendah 58 untuk tes akhir pertama dan rata-rata sebesar 70.12, dengan nilai terendah 44 dan tertinggi 88 , adapun sekala yang digunakan adalah 100 , hal ini tercapai setelah peneliti melakukan perkuliahan dengan menggunakan peta konsep. 3) Hasil analisis dari penelitian ini menggambarakan bahwa perkuliahan melalui pendekatan peta konsep dapat peningkatan kemampuan pemecahan masalah dan hasil belajar mahasiswa pada Mata Kuliah Matematika Dasar, hal ini sesuai dengan criteria peningkatan yang penulis uji dengan menggunakan gain ternormalisasi dengan criteria cukup ; 4)Hasil analisis data tentang sekala sikap menunjukan bahwa ikap mahasiswa terhadap perkuliahan menggunakan menyusun peta konsep pada Mata Kuliah Matematika Dasar adalah positif.

\section{Kesimpulan Dan Rekomendasi}

Kesimpulan hasil penelitian sebagai berikut:

1. Pencapaian hasil perkuliahan matematika dasar mahasiwa prodi Matematika sebelum pembelajaran melalui peta konsep termasuk kategori rendah, hal ini terlihat dari nilai rata-rata hasil pretes 1 dan 2.

2. pencapaian hasil perkuliahan matematika dasar mahasiwa prodi Matematika melalui penyusuanan peta konsep termasuk kategori baik hal ini terlihat dari nilai rata-rata hasil prostes 1 dan 2 .

3. Terjadi peningkatan hasil perkuliahan setelah perkuliahan menggunakan menyusun peta konsep pada mata Kuliah Matematika Dasar, hal ini terlihat dari hasil uji statistic dimana hasil uji t tes menunjukan bahwa hipotesis diterima serta hasil pengujian gain ternormalisai menunjukan kategori sedang.

4. sikap mahasiswa terhadap perkuliahan menggunakan menyusun peta konsep pada mata kuliah Matematika Dasar termasuk kategori baik.

Rekomendasi yang diajukan

1. Kesimpulan penelitian diatas, menyatakan bahwa pembelajaran yang disertai penyusunan peta konsep dapat meningkatkan kemampuan pemecahan masalah mahasiswa. Dalam upaya meningkatkan kemampuan pemecahan masalah matematika mahasiwa dapat digunakan sebagai salah satu alternatif strategi perkuliahan.

2. Perkuliahan dengan pendekatan penyusunan peta konsep merupakan alternatif perkuliahan untuk mata kuliah lain, maka dosen bisa memilih untuk diterapkan.

Penelitian ini baru merupakan awal dan terbatas pada satu kelas mahasiswa di prodi matematika Fakultas Tarbiyah UIn Sunan Gunung Djati bandung, maka diharapkan kepada peneliti lain untuk memperluas permasalahnya. Misalnya dapat diterapkan pada materi lain dan bahkan sampelnya dapat diperluas. 


\section{DAFTAR PUSTAKA}

Ambo, Saka, 1988, Pembelajaran Matematika dengan Modal Pencapaian Konsep, Tesis tidak dipublikasikan, PPS IKIP Surabaya.

Arends, Richard, 1997 Classroom Intruction and Management, MC Grow-Hill Companics Inc., New York.

Arikunto, Suharsimi, 1997, Dasar-dasar Evaluasi Pendidikan, Bumi Aksara, Jakarta.

Ausebel, DP 1968, Educational Phychology, A Cognitive View, Holt, Rinerhert and Winston Inc., New York.

Anas Sudjono, 2007Pengantar Evaluasi Pendidikan, Jakarta: Raja Grafindo.

Bobbi Deppoter, 2002Quantum Teaching, Mempraktekkan Quantum Learning di Ruang Kelas, Bandung; Kaifa.

Dahar, Ratna Wilis, 1989, Teori-teori Belajar, Erlangga, Jakarta.

Gagne, Robert M, Briggs, Leslie J, 1979, Principles of Intructional Design, Holt Rinerhert and Winston Inc., New York.

Hudojo, Herman, 1979, Pengembangan Kurikulum Matematika dan Pelaksanaannya di Depan Kelas, Usaha Nasional, Surabaya.

Isa, M, 1996, Pengaruh Strategi Belajar Mengajar dengan Bantuan Pemetaan Konsep Melalui Kerja Kelompok Terhadap Hasil Belajar Siswa, Thesis tidak dipublikasikan, PPS IKIP Bandung.

Kusumah, Ibnu Hardi, 1992, Studi Tentang Strategi Belajar Mengajar Menggunakan Pemetaan Konsep, Tesis tidak dipublikasikan, PPS IKIP Bandung.

Novak, JD and Gowin, GB, 1985, Learning How Learn, Cambridge University Press, Sydney.

Nyoman Muliasa,2002 Penggunaan Peta Konsep dalam Pembelajaran (makalah), Malang: Program pasca Sarjana UNM,

Nasution. S, 1984, Berbagai Pendekatan dalam Proses Belajar dan Mengajar, Bina Aksara, Jakarta.

Prabowo, Hadisubroto, T, Barto, 1996, Peranan Peta Konsep dalam Pembelajaran Manggunakan Pendekatan Keterampilan Proses, (Studi Eksperimental Pembelajaran IPA di SMP), Laporan Penelitian tidak dipublikasikan, IKIP Surabaya.

Purwanto, N, 1997, Prinsip-prinsip dan Teknik Evaluasi Pengajaran, P.T. Remaja Rosdakarya, Bandung.

Ruseffendi, E.T, 1994, Dasar-dasar Penelitian Pendidikan dan Bidang Non-Eksakta lainnya, IKIP Semarang.

Ruseffendi, E.T. 2006. Pengantar kepada Membantu Guru Mengembangkan Kompetensinya dalam Pengajaran Matematika untuk Meningkatkan CBSA. Bandung: Tarsito.

Rachmawati, Yeni. 2005. Penerapan Peta Konsep dan Pengaruhnya TerhadapPeningkatan Penguasaan MateriPerkuliahan Mahasiswa PGTK. Action Research pada Mata KuliahPsikologi Perkembangan II diPGTK FIP UPI (tidak dipublikasikan).

Ramdani, Yani. 2000, Pembelajaran untuk Meningkatkan Kemampuan Koneksi Matematika Siswa SekolahMenengah Umum Melalui Penyusunan Peta Konsep. Tesis UPI(tidak dipublikasikan).

Seber, G.A.F, 1984, Multivariate Observations, John Wiley \& Sons, Inc., New York.

Soejadi, R, 1994, Memantapkan Matematika Sekolah sebagai Wahana Pendidikan dan Pembudayaan Penalaran, FPMIPA IKIP Surabaya.

Subino, 1987, Kontruksi dan Analisis Tes, Dirjen Dikti Depdikbud, Jakarta.

Suparno, Paul, 1997, Filsafat Konstruktivisme dalam Pendidikan, Kanisisus.

William Clark Trow, 1979, Teaching and Learning, Ram Nagar, New Delhi.

Wilcox, Sandra K, 1998, Another Perspective on Concept Maps Empowering Students, Mathematics Teaching in The Middle School, Vol. 3, No. 7, Pp 464- 46

Zulkardi. 2003. Pendidikan Matematika di Indonesia : Beberapa Permasalahan dan Upaya Penyelesaiannya. Palembang: Unsri. 


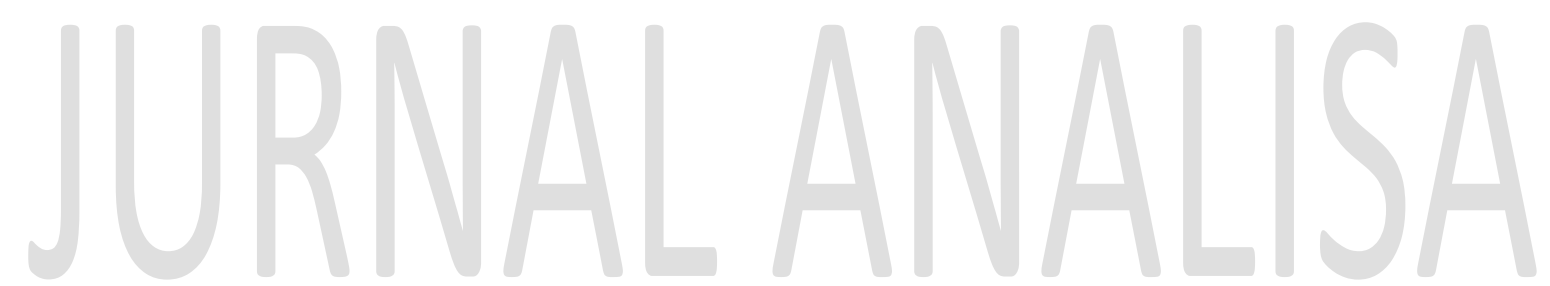

